\title{
Determinan Earnings Response Coefficient dan Peran Konservatisme Akuntansi sebagai Pemoderasi pada Perusahaan Property dan Real Estate
}

\author{
Rina Nurmalina ${ }^{1}$, Suratno ${ }^{2}$, Widarto ${ }^{3}$, Syahril Djaddang ${ }^{4}$ \\ 1.2.2.3.4 Universitas Pancasila, Jl. Srengseng Sawah, Jagakarsa, Jakarta Selatan, 12640
}

\section{INFO ARTIKEL}

JEL Classsification:

M41

G11

Keywords:

Leverage, Investment

Opportunity

Set, Accounting

Conservatism,

Profitability

\section{ABSTRACT}

The purpose of this study is to examine the factors that influence the earnings response coefficient consisting of leverage, profitability, and investment opportunities that are moderated by accounting conservatism in companies listed on the Indonesia Stock Exchange in the period 2011-2017. The selection of a sample of 49 year data was used with the purposive sampling method. The results of this study indicate that, leverage has a negative effect on earnings response coefficients. Profitability, investment opportunity sets and accounting conservatism have no significant effect on earnings response coefficients. Conservatism accounting does not moderate the relationship between leverage and profitability to the earnings response coefficient. Conservative accounting moderates the relationship between investment opportunities set at the earnings response coefficient.

\begin{abstract}
ABSTRAK
Tujuan dari penelitian ini adalah untuk menguji faktor-faktor yang mempengaruhi koefisien respon laba yang terdiri dari leverage, profitabilitas, dan peluang investasi yang dimoderasi oleh konservatisme akuntansi pada perusahaan yang terdaftar di Bursa Efek Indonesia pada periode 2011-2017. Pemilihan sampel sejumlah 49 data tahun digunakan dengan metode purposive sampling. Hasil penelitian ini menunjukkan bahwa, leverage berpengaruh negatif terhadap koefisien respon laba. Profitabilitas, set kesempatan investasi dan konservatisme akuntansi tidak berpengaruh signifikan terhadap koefisien respon laba. Akuntansi konservatisme tidak memoderasi hubungan antara leverage dan profitabilitas terhadap koefisien respons laba. Akuntansi konservatisme memoderasi hubungan antara peluang investasi yang ditetapkan pada koefisien respons laba.
\end{abstract}

\section{Pendahuluan}

Laba merupakan bagian dari informasi keuangan yang paling banyak diminta oleh pasar keuangan. Secara konseptual, laba bertujuan untuk memberikan pengukuran pada perubahan kekayaan pemegang saham (stakeholder) selama satu periode dan estimasi profitabilitas bisnis saat ini, yaitu sampai seberapa besar bisnis tersebut dapat menutupi biaya operasi dan memperoleh imbal hasil untuk para pemegang sahamnya (Subramanyam, 98;2017). Dalam SFAC No. 1 disebutkan bahwa informasi laba merupakan komponen laporan keuangan yang disediakan dengan tujuan membantu menyediakan informasi untuk menilai kinerja

*Email Korespondensi: ${ }^{1}$ rinanurmalina5@gmail.com 
manajemen, mengestimasi kemampuan laba yang representative dalam jangka panjang dan menaksir resiko dalam investasi dan kredit. Sehingga informasi laba menjadi sangat utama terutama bagi pemegang saham atas pengembalian modal atau keuntungan yang harus didapatkan dari sebuah investasi. Dengan demikian, informasi laba akan memicu reaksi investor untuk mengambil keputusan dalam berinvestasi. Dapat dikatakan bahwa informasi akuntansi yang relevan yaitu dengan mengamati reaksi investor saat diumukan informasi yang tercermin dari perubahan harga saham.

Pengukuran reaksi investor diproksikan dengan Earnings Response Coefficient (ERC) yang merupakan respon pasar atas laba yang terjadi pada perusahaan, yang terkandung dalam harga saham. ERC digunakan pula sebagai ukuran dari kualitas laba. ERC menunjukkan hubungan antara laba dan return saham. ERC menggunakan Cumulative Abnormal Return (CAR) sebagai variabel dependen dan unexpected earnings sebagai variabel independen. Besarnya koefisien dari hasil regresi disebut koefisien respon laba. Semakin tinggi koefisien respon laba menunjukkan tingginya respon investor terhadap pengumuman laba, hal tersebut juga menunjukkan informasi laba yang semakin berkualitas.

Studi kasus yang diangkat pada penelitian ini yaitu perusahaan yang bergerak di bidang Real Estate dan Property.

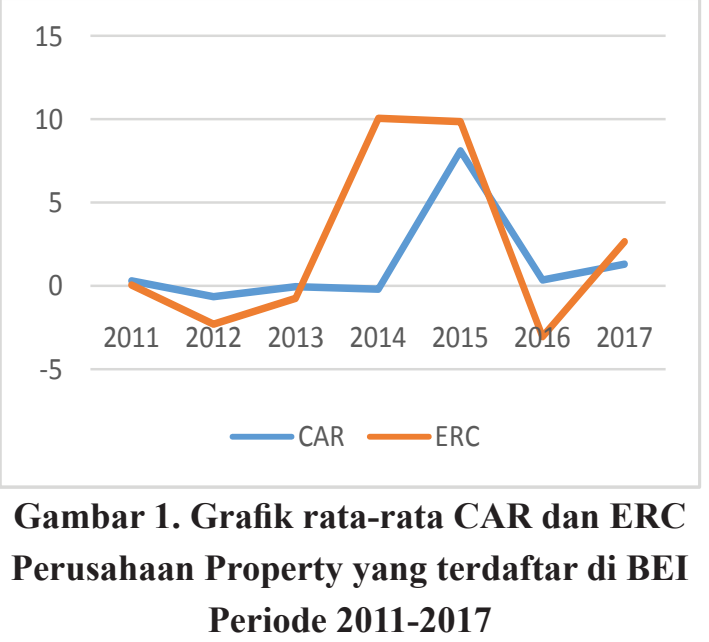

Grafik pada gambar 1.1 menunjukan respon investor atas laba perusahaan pada periode 20112017. Earnings Response Coefficient (ERC) dan Cumulative Abnormal Return (CAR), pada tahun 2014 terjadi gap yang cukup jauh antara CAR (-0.23) dengan ERC (10.05), hal ini menandakan bahwa informasi laba tidak secara signifikan direspon pasar. Pada tahun 2016, informasi laba tidak mencerminkan kualitas laba yang ditunjukkan dengan nilai ERC negatif (-3.05). Nilai tersebut menunjukkan respon pasar yang terkandung dalam harga saham (abnormal return) berbanding terbalik atas perubahan yang terjadi pada laba (unexpected earnings).

Hal tersebut memberikan gambaran lain bahwa informasi laba saja tidak cukup untuk dijadikan dasar dalam pengambilan keputusan investor. Semakin berkualitas laba akuntansi maka semakin tinggi respon investor. Kualitas laba tidak berhubungan dengan tinggi atau rendahnya laba yang dilaporkan, menurut Husiano (2015) kualitas laba meliputi understatement dan overstatement dari laba (bersih), stabilitas komponen dalam laporan rugi laba, realisasi resiko asset, pemeliharaan atas modal, dan dapat merupakan prediktor laba masa depan (predictive value).

Beberapa penelitian telah melakukan penelitian mengenai earnings response coefficient dengan beberapa faktor yang mempengaruhinya. Penelitian Mulyani (2007) meneliti faktor-faktor yang mempengaruhi earnings response coefficient yaitu persistensi laba, struktur modal, investment opportunity set, ukuran perusahaan dan kualitas aditor. Menurut Jung (1991) dalam Sondang (2017) faktor-faktor yang mempengaruhi ERC adalah: persistensi laba, pertumbuhan perusahaan, risiko, ukuran perusahaan, dan efek industri. Sedangkan menurut Suhartono (2015) faktor yang mempengaruhi ERC yaitu konservatisme akuntansi, ketepatan waktu penyampaian laporan keuangan dan leverage. Sedangkan pada penelitian ini digunakan variabel investment opportunity set, leverage, profitabilitas dan 
konservatisme akuntansi sebagai variabel independen yang mempengaruhi earnings response coefficient.

Leverage ratio merupakan rasio yang digunakan untuk mengukur seberapa besar aktiva perusahaan dibiayai dengan hutang. Artinya berapa besar beban hutang yang ditanggung perusahaan dibandingkan dengan aktivanya. Perusahaan yang memiliki tingkat hutang yang tinggi memiliki kewajiban terhadap debitur untuk melunasi hutangnya. Sedangkan perusahaan juga memiliki kewajiban terhadap investor. Selain itu, tingkat hutang yang tinggi menunjukkan beban perusahaan dalam menyelesaikan kewajiban dan keberlangsungan hidup perusahaan. Hal ini akan mempengaruhi reaksi atau respon dari investor terhadap perusahaaan dalam mengambil keputusan. Penelitian Husiano (2015) menyatakan bahwa leverage berpengaruh positif terhadap ERC.

Rasio Profitabilitas merupakan rasio untuk menilai kemampuan perusahaan dalam mencari keuntungan. Profitabilitas merupakan salah satu faktor yang mempengaruhi koefisien respon laba. Hasanzade et al (2013) menyatakan bahwa profitabilitas mengacu pada kemampuan perusahaan untuk mendapatkan keuntungan, dimana profitabilitas merupakan hasil akhir dari program perusahaan dan keputusan keuangan. Semakin tinggi tingkat profitabilitas perusahaan maka akan semakin tinggi respon investor dan sebaliknya. Beberapa penelitian telah menyimpulkan bahwa profitabilitas mempengaruhi earnings response coefficient (Aryanti, 2016; Hasanzade, 2013). Namun, hasil ini masih memiliki perbedaan hasil penelitian bahwa profitabilitas tidak berpengaruh terhadap ERC (Santoso, 2015).

Keberlangsungan perusahaan menjadi salah satu penilaian investor untuk berinvestasi. Investment opportunity set (IOS) merupakan kesempatan yang dimiliki oleh suatu perusahaan untuk bertumbuh. IOS dapat digunakan sebagai dasar untuk menentukan klasifikasi pertumbuhan perusahaan dimasa mendatang.
Semakin tinggi Investment opportunity set maka kesempatan dalam memperoleh laba masa depan lebih besar sehingga hal ini akan berpengaruh terhadap ERC. Beberapa penelitian menyebut Investment opportunity set sebagai kesempatan bertumbuh, penelitian tersebut menyimpulkan bahwa kesempatan bertumbuh atau investment opportunity set perusahaan berpengaruh terhadap earnings response coefficient (Purwanto, 2017). Hal berbeda juga dikemukakan oleh Santoso (2015) yang menyimpulkan bahwa tidak ada pengaruh dari peluang bertumbuh suatu perusahaan terhadap ERC.

Faktor lainnya yaitu konservatisme akuntansi yang merupakan salah satu prinsip pencatatan akuntansi. Akuntansi konservatif masih mempunyai peranan penting sampai saat ini karena prinsip ini memiliki pengaruh terhadap penilaian dalam akuntansi. Konservatisme merupakan reaksi yang hati-hati (prudentreaction) dalam menghadapi ketidakpastian yang melekat pada perusahaan untuk mencoba memastikan bahwa ketidakpastian dan risiko dalam lingkungan bisnis sudah cukup dipertimbangkan. Dengan prinsip kehati-hatian maka akan dapat membatasi tindakan manajemen dalam membesar-besarkan laba. Penelitian yang dilakukan Suhartono (2015) membuktikan bahwa penerapan konservatisme menjadikan perusahaan melaporkan nilai laba dan aktiva bersih yang lebih rendah, sehingga menjadikan kualitas laba yang baik dan kondisi perusahaan yang aman. Bagi sebagian investor kondisi laba yang demikian, akan lebih menarik karena investasi yang ditanamkan akan dirasakan aman, meskipun memiliki nilai laba yang rendah.

Berdasarkan uraian yang telah disajikan diatas maka rumusan masalah penelitian adalah "Bagaimana pengaruh leverage, profitabilitas, investment opportunity set dengan konservatisme akuntansi sebagai moderasi terhadap earnings response coefficient (ERC)?”.

Tujuan dari penelitian ini adalah untuk mengetahui seberapa besar pengaruh leverage, 
Rina, Suratno, Widarto, Syahril: Determinan Earnings Response Coefficient...

profitabilitas, investment opportunity set dengan konservatisme akuntansi.

\section{Telaah Teori dan Pengembangan Hipotesis}

\section{Pengaruh Leverage Terhadap Earnings Response Coefficient}

Leverage merupakan rasio yang digunakan untuk mengukurseberapa besaraktiva perusahaan dibiayai dengan hutang. Investor tentunya mengharapkan keuntungan atas investasinya serta memiliki nilai di masa depan yang dapat menjaga keberlangsungan perusahaan sehingga mempengaruhi return dari invesatasinya. Ketika rasio leverage yang ditunjukkan oleh Debt to Equity Ratio cenderung tinggi menandakan bahwa pembiayaan perusahaan lebih banyak dibiayai dari hutang dibandingkan dana yang bersumber dari pemegang saham. Mulyani (2007) mengatakan bahwa perusahaan dengan tingkat leverage tinggi berarti memiliki hutang yang lebih besar dibandingkan modal. Sehingga perusahaan dengan tingkat hutang yang tinggi memiliki beban yang tinggi atas kewajiban yang harus dibayar, hal ini akan direspon negatif oleh investor.

Penelitian yang dilakukan oleh Rahayu (2012) menyimpulkan bahwa konservatisme laba berhubungan positif dengan ERC. Penelitian Suhartono (2015) juga menyimpulkan bahwa konservatisme akuntansi memoderasi memberikan pengaruh negatif terhadap pengaruh leverage terhadap ERC. Respon negatif dari para investor akan berkurang ketika perusahaan menerapkan prinsip konservatisme akuntansi. Hal ini dapat terjadi karena sebagian investor yakin bahwa perusahaan yang menerapkan konservatisme akuntansi akan lebih berhatihati dalam mengakui keuntungan dan segera mengakui kerugian maupun hutang yang kemungkinan akan terjadi, sehingga perusahaan lebih aman. Dengan demikian, hipotesis penelitian ini yaitu:

$\mathrm{H}_{1}$ : Leverage berpengaruh signifikan negatif terhadap earnings response coefficient
$\mathrm{H}_{\text {la }}$ : Konservatisme akuntansi memoderasi pengaruh leverage terhadap earnings response coefficient

\section{Pengaruh Profitabilitas Terhadap Earnings Response Coefficient}

Rasio profitabilitas merupakan rasio untuk menilai kemampuan perusahaan dalam mencari keuntungan. Penggunaan rasio profitabilitas dapat dilakukan dengan menggunakan perbandingan antara berbagai komponen yang ada di laporan keuangan, terutama laporan laba rugi dan laporan posisi keuangan. Tujuannya adalah agar terlihat perkembangan perusahaan dalam rentang waktu tertentu, baik penurunan atau kenaikan, sekaligus mencari penyebab perubahan tersebut. Profitabilitas mencerminkan keefektivan perusahaan yang mempengaruhi respon investor terhadap informasi laba dalam pengambilan keputusan investasi. Perusahaan yang baik adalah perusahaan yang memiliki efisiensi operasional yang baik, sehingga memiliki tingkat profitabilitas yang tinggi. Semakin tinggi tingkat profitabilitias sebuah perusahaan maka diharapkan semakin tinggi earning response coefficient.

Penelitian Aryanti (2016) menyimpulkan bahwa semakin tinggi tingkat profitabilitas, maka earnings response coefficient akan semakin meningkat. Sebaliknya, semakin rendah tingkat profitabilitas, maka earnings response coefficient akan semakin menurun. Hasil penelitian ini konsisten dengan penelitian sebelumnya yang dilakukan oleh Hasanzade (2013). Tingkat profitabilitas yang tinggi pada perusahaan akan meningkatkan daya saing antar perusahaan. Tingkat keuntungan yang tinggi menunjukkan tingkat pertumbuhan perusahaan pada masa mendatang. Sehingga perusahaan dengan profitabilitas yang tinggi akan memiliki kesempatan bersaing yang lebih baik.

Prinsip kehati-hatian atau konservatisme akuntansi dapat digunakan dalam keadaan perekonomian yang tidak stabil. Prinsip konservatisme akuntansi sebagai prinsip 
kehati-hatian dalam merespon ketidakpastian, dengan memastikan bahwa ketidakpastian dan risiko bisnis sudah dipertimbangkan secara memadai. Handojo (2012) yang menyatakan konservatisme akuntansi tidak mengantisipasi profit sama sekali, namun mengantisipasi segala kerugian. Marselina dan Sebrina (2014) mendefinisikan konservatisme sebagai sikap atau aliran (mazhab) dalam menghadapi ketidakpastian untuk mengambil tindakan atau keputusan atas dasar munculan (outcome) yang terjelek dari ketidakpastian tersebut. Dengan demikian, investor yakin bahwa perusahaan yang menerapkan konservatisme akuntansi akan lebih berhati-hati dalam mengantisipasi segala bentuk kerugian yang kemungkinan akan terjadi, sehingga perusahaan lebih aman. Maka, hipotesis dalam penelitian ini yaitu:

$\mathrm{H}_{2}$ : Profitabilitas berpengaruh signifikan positif terhadap earnings response coefficient

$\mathrm{H}_{2 \mathrm{a}}$ : Konservatisme akuntansi memoderasi pengaruh profitabilitas terhadap earnings response coefficient

\section{Pengaruh Investment Opportunity Set Terhadap Earnings Response Coefficient}

Investment opportunity set bisa dikatakan sebagai kesempatan bertumbuh suatu perusahaan. Investasi yang dilakukan oleh perusahaan ini dapat menghasilkan pertumbuhan yang riil dimasa mendatang dan menghasilkan return sehingga nilai perusahaan meningkat. Selain infomasi laba, investor juga menginginkan adanya keberlangsungan atas kepemilikan yang dimiliki di perusahaan agar berkembang. Sehingga ketika perusahaan memiliki peluang bertumbuh yang ditunjukkan dengan investment opportunity set maka investor cenderung akan tertarik untuk berinvestasi pada perusahaan. Penelitian mengenai kesempatan bertumbuh dilakukan oleh Nisrina dan Vinola (2016), hasil penelitiannya menyimpulkan bahwa investment opportunity set berpengaruh positif terhadap keinformatifan laba yang diproksikan dengan earnings response coefficient. Artinya bahwa semakin besar investment opportunity set perusahaan maka semakin tinggi kesempatan perusahaan mendapatkan atau menambah laba yang diperoleh perusahaan pada masa mendatang sehingga semakin tinggi earnings response coefficient (ERC) dimasa yang akan datang. Hasil penelitian tersebut sejalan dengan penelitian yang dilakukan oleh (Mulyani; 2007, Purwanto; 2017).

Dalam realisasinya investment opportunity set tidak selalu menunjukkan nilai yang positif sehingga perusahaan perlu mengantisipasi hal tersebut. Prinsip kehati-hatian atau konservatisme akuntansi dapat digunakan dalam keadaan perekonomian yang tidak stabil. Setyaningtyas (2009) menyatakan bahwa laporan keuangan yang cenderung konservatif disebabkan oleh perilaku high risk adverse investor sehingga konservatisme dianggap sebagai good news. Sehingga penerapan akuntansi dapat memberikan pengaruh positif bagi kinerja perusahaan yang dapat meningkatkan nilai perusahaan di mata investor. Sehingga hipotesis dari penelitian ini yaitu:

$\mathrm{H}_{3}$ : Investment opportunity set berpengaruh signifikan positif terhadap earnings response coefficient

$\mathrm{H}_{3 \mathrm{a}}$ : Konservatisme akuntansi memoderasi pengaruh investment opportunity set perusahaan terhadap earnings response coefficient

\section{Pengaruh Konservatisme Akuntansi Terhadap Earnings Response Coefficient}

Konservatisme dalam konsep No.2 FASB (Financial Accounting Statement Board) diartikan sebagai reaksi yang hati-hati (prudentre action) dalam menghadapi ketidakpastian yang melekat pada perusahaan untuk mencoba memastikan bahwa ketidakpastian dan risiko dalam lingkungan bisnis yang sudah cukup dipertimbangkan. Konservatisme menganut prinsip memperlambat pengakuan pendapatan serta mempercepat pengakuan biaya. Akibatnya, laba yang dilaporkan cenderung terlalu rendah (understatement). 
Penelitian Suhartono (2015) membuktikan bahwa konservatisme akuntansi berpengaruh positif terhadap koefisien respon laba. Penerapan konservatisme menjadikan perusahaan melaporkan nilai laba dan aktiva bersih yang lebih rendah, sehingga menjadikan kualitas laba yang baik dan kondisi perusahaan yang aman. Bagi sebagian investor kondisi laba yang demikian, akan lebih menarik, karena investasi yang ditanamkan akan dirasakan aman, meskipun memiliki nilai laba yang lebih rendah. Penelitian ini sejalan dengan penelitian yang dilakukan oleh Wulandari (2015) dan Basuki (2017) bahwa konservatisme akuntansi berpengaruh terhadap earnings response coefficient. Sehingga, hipotesis penelitian ini yaitu:

$\mathrm{H}_{4}$ : Konservatisme berpengaruh signifikan positif terhadap earnings response coefficient

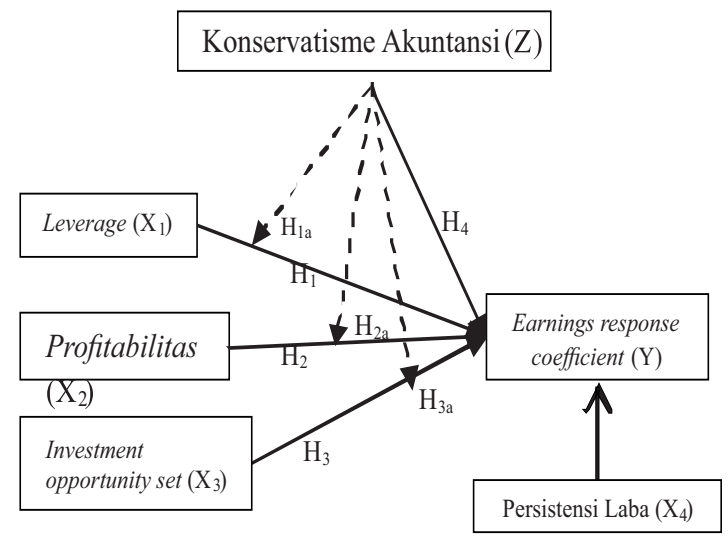

Gambar 2. Kerangka Pemikiran

\section{Metode Penelitian}

Penelitian ini menggunakan metode penelitian kuantitatif. Populasi yang digunakan dalam penelitian yaitu perusahaan Property dan Real Estate yang terdaftar di BEI tahun 20112017. Pengambilan sampel menggunakan teknik purposive sampling. Data yang digunakan yaitu data sekunder yang berasal dari laporan keuangan tahunan dan harga saham perusahaan yang terdaftar pada Bursa Efek Indonesia (BEI) yang diperoleh dari website yaitu idx.co.id.
CAR merupakan proksi harga saham atau reaksi pasar. Pada penelitian ini cumulative abnormal return dalam jendela pengamatan yaitu 3 (tiga) sebelum dan 3 (tiga) hari setelah publikasi laporan keuangan. Unexpected Earning atau laba kejutan adalah selisih antara laba sesungguhnya dengan laba ekspektasian yang diukur menggunakan pengukuran Suaryana (2004). ERC merupakan koefisien yang diperoleh dari regresi antara proksi harga saham dan laba akuntansi. Proksi harga saham yang digunakan adalah CAR, sedangkan proksi laba akuntansi adalah UE.

Leverage merupakan perbandingan atau imbangan pendanaan jangka panjang perusahaan yang ditunjukkan oleh perbandingan hutang jangka panjang terhadap modal sendiri. Rasio profitabilitas merupakan rasio untuk menilai kemampuan perusahaan dalam mencari keuntungan. Profitabilitas perusahaan diukur dengan menggunakan rasio laba terhadap nilai buku ekuitas yang dapat mencerminkan hasil penggunaan sumber daya perusahaan. Investment opportunity set merupakan kesempatan yang dimiliki oleh suatu perusahaan untuk bertumbuh. IOS dapat digunakan sebagai dasar untuk menentukan klasifikasi pertumbuhan perusahaan di masa mendatang.

Tingkat konservatisme, diukur dengan total akrual yang merupakan penjumlahan selisih laba bersih sebelum kejadian luar biasa dengan arus kas operasi selama 3 tahun dimulai dua tahun sebelum tahun observasi, dibagi dengan total aset tahun yang bersangkutan. Persistensi laba akuntansi $\left(\mathrm{PTBI}_{\mathrm{t}+1}\right)$ merupakan laba perusahaan sebelum pajak dan pos luar biasa. 
Tabel 1. Definisi Operasionalisasi Variabel

\begin{tabular}{|c|c|c|c|c|c|}
\hline No & Variabel & $\begin{array}{l}\text { Sub } \\
\text { Var. }\end{array}$ & Indikator & Skala & Referensi \\
\hline 1. & $\begin{array}{l}\text { Earning } \\
\text { Response } \\
\text { Coefficient } \\
\text { (ERC) }\end{array}$ & ERC & $\boldsymbol{C A} \boldsymbol{R}_{i t}=\alpha_{0}+\alpha_{11} \mathrm{UE}+\mathrm{e}$ & Rasio & $\begin{array}{c}\text { Brown } \\
\text { dan } \\
\text { Warner } \\
\text { (1985) }\end{array}$ \\
\hline 2. & Leverage & DER & $D E R=\frac{\text { Total Utang }}{\text { Total Equity }}$ & Rasio & Kasmir \\
\hline 3. & Profitabilitas & $\mathrm{ROE}$ & $R O E=\frac{\text { Net Income }}{\text { Equity }}$ & Rasio & $\underset{(2013)}{\text { Kasmir }}$ \\
\hline 4. & $\begin{array}{l}\text { Investment } \\
\text { opportunity } \\
\text { set }\end{array}$ & IOS & $\begin{array}{l}\frac{M V}{B V} \\
=\frac{T A-T E+(L S B x H P S)}{T A}\end{array}$ & Rasio & $\begin{array}{l}\text { Kallapur } \\
\text { dan } \\
\text { Trombley } \\
\text { (1999) }\end{array}$ \\
\hline 5. & $\begin{array}{l}\text { Konservatisme } \\
\text { Akuntansi }\end{array}$ & $\mathrm{CA}$ & $\frac{\mathrm{NI}_{t}+\mathrm{Dep}_{t}-\mathrm{CFO}_{t} \times-1}{\mathrm{TA}} \times$ & Rasio & $\begin{array}{l}\text { Givoly } \\
\text { and Hayn } \\
(2002)\end{array}$ \\
\hline 6. & $\begin{array}{c}\text { Earnings } \\
\text { Persistence }\end{array}$ & РTB & $\begin{array}{c}\text { PTBI }_{i t}=\alpha+\text { BPTBI }_{\text {it-1 }}+ \\
e_{i}\end{array}$ & Rasio & $\begin{array}{l}\text { Sloan } \\
(1996)\end{array}$ \\
\hline
\end{tabular}

Sumber: Data diolah penulis (2018)

Penelitian ini menggunakan Moderated Regression Analysis (MRA). Berdasarkan kerangka pemikiran dan pengembangan hipotesis, persamaan analisis moderasi yang akan diuji yaitu:

\section{$\mathrm{ERC}=\alpha+\boldsymbol{\beta}_{1} \mathrm{DER}+\boldsymbol{\beta}_{2 .} \mathrm{ROE}+\boldsymbol{\beta}_{3} \cdot \mathrm{IOS}+\boldsymbol{\beta}_{4} \cdot \mathrm{CA}+\boldsymbol{\beta}_{5}$. DER.CA $+\beta_{6} \cdot$ ROE.CA $+\beta_{7} \cdot$ IOS.CA $+\varepsilon$}

Keterangan:

$$
\begin{aligned}
\mathrm{ERC}= & \text { earnings response coefficients } \\
\alpha= & \text { konstanta } \\
\boldsymbol{\beta}_{1}= & \text { koefisien Debt to Equity Ratio } \\
\boldsymbol{\beta}_{2}= & \text { koefisien Return on Equity } \\
\boldsymbol{\beta}_{3}= & \text { koefisien Investment opportunity set } \\
\boldsymbol{\beta}_{4}= & \text { koefisien Conservatism Accountancy } \\
\boldsymbol{\beta}_{5}= & \text { koefisien Debt to Equity Ratio dan } \\
& \text { Conservatism Accountancy } \\
\boldsymbol{\beta}_{6}= & \text { koefisien Return on Equity dan } \\
& \text { Conservatism Accountancy } \\
\boldsymbol{\beta}_{7}= & \text { koefisien Investment opportunity set } \\
& \text { dan Conservatism Accountancy } \\
\text { DER = } & \text { Debt to Equity Ratio } \\
\text { ROE = } & \text { Return on Equity }
\end{aligned}
$$

$$
\begin{aligned}
\mathrm{IOS} & =\text { Investment opportunity set } \\
\mathrm{CA} & =\text { Conservatism Accountancy } \\
\varepsilon \quad & =\text { error term }
\end{aligned}
$$

\section{Hasil dan Pembahasan}

Populasi dalam penelitian ini yaitu perusahaan Property dan Real Estate yang terdaftar di BEI pada tahun 2011-2017 sebanyak 49 perusahaan. Pemilihan sampel yang digunakan dalam penelitian ini yaitu purposive sampling dengan kriteria yang telah ditentukan, yaitu (1) perusahaan terdaftar pada Bursa Efek Indonesia periode 2011-2017; (2) Laporan keuangan perusahaan yang telah diaudit, dipublish di BEI dan berada pada tahun pengamatan 2010-2017; (3) Laporan keuangan perusahaan telah memenuhi komponen laporan keuangan yang diperlukan dalam penelitian yaitu, leverage, profitabilitas, investment opportunity set konservatisme akuntansi dan persistensi laba. Sehingga didapatkan 63 sampel selama periode penelitian. 
Tabel 2. Deskriptif Statistik Penelitian

\begin{tabular}{lcccc}
\hline & $\mathbf{N}$ & Maximum & Minimum & Mean \\
\hline ERC & 63 & 10.59 & 0.00 & 0.97 \\
DER & 63 & 1.96 & 0.15 & 0.89 \\
ROE & 63 & 0.33 & 0.01 & 0.15 \\
IOS & 63 & 3.86 & 0.32 & 1.43 \\
CA & 63 & 0.19 & -0.19 & -0.00 \\
EP & 63 & 2.18 & 0.16 & 0.75 \\
\hline
\end{tabular}

Sumber: data diolah penulis (2018)

Tabel 3. Model Fit Penelitian

\begin{tabular}{ccc}
\hline & Indeks & P-Value \\
\hline APC & 0.18 & 0.05 \\
ARS & 0.68 & $<0.00$ \\
AVIF & 1.46 & $3.3-5$ \\
\hline
\end{tabular}

Sumber : Hasil WarpPLS (data diolah)

Hasil output diatas, menjelaskan bahwa nilai APC memiliki indeks sebesar 0.18 dengan nilai p-value 0.05. Sedangkan ARS memiliki indeks sebesar 0.68 dengan p-value $<0.00$. Nilai P-value dari kedua indeks menunjukkan hasil dibawah 0.05 (pada alpha 5\%) yang berarti memenuhi kriteria APC dan ARS. Nilai AVIF yang dihasilkan juga menunjukan indeks dibawah 5 yaitu sebesar 1.46. Sehingga dapat ditarik kesimpulan bahwa model mampu memprediksi nilai observasinya atau dapat dikatakan model dapat diterima karena cocok dengan data observasinya (Ghozali, 2011).

Koefisien determinasi $\left(\mathrm{R}^{2}\right)$ dalam penelitian inibertujuanmengukurseberapajauhkemampuan variabel independen (Leverage, Profitabilitas, Investment opportunity set) dalam menjelaskan variasi variabel dependen (Earnings response coefficient) dengan menggunakan variabel moderasi (konservatisme akuntansi) dan variabel kontrol (persistensi laba). Berdasarkan gambar. 2 terlihat nilai koefisien determinasi $\left(\mathrm{R}^{2}\right)$ sebesar 0.68 atau sebesar $68 \%$. Kemampuan variabelvariabel independen dalam menjelaskan variasi variabel dependen yaitu sebesar $68 \%$ informasi yang manjelaskan variabel earnings response coefficient sisanya sebesar $32 \%$ dijelaskan oleh variabel lain di luar penelitian ini.

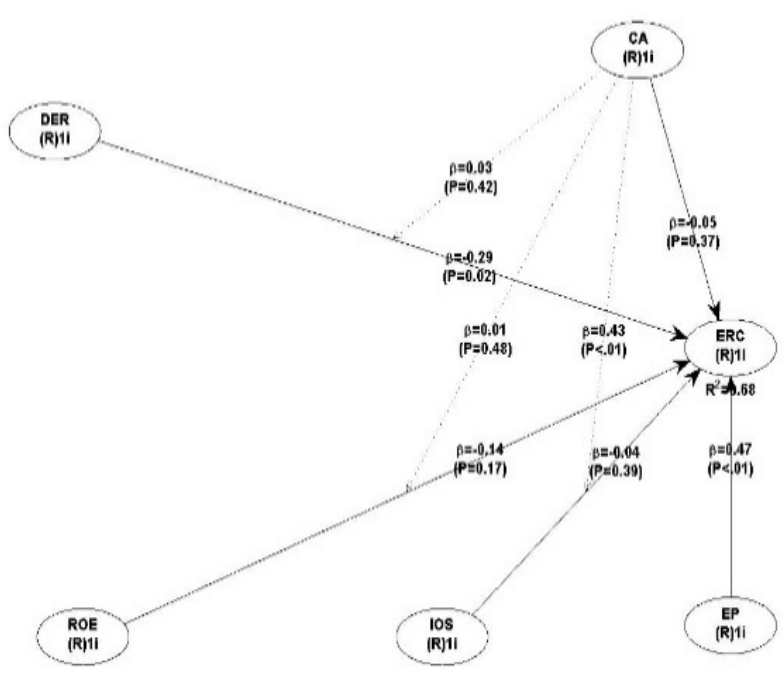

\section{Gambar 3. Model Struktural dengan Single Moderator}

Penjelasan mengenai pengaruh variabelvariabel independen terhadap variabel dependen dengan menggunakan konservatisme akuntansi sebagai variabel moderasi berdasarkan table 4 diuraikan sebagai berikut:

1. Pengaruh leverage terhadap earnings response coefficient dapat dilihat nilai p-value yang dihasilkan 0.02 dengan koefisien jalur sebesar -0.29 , sehingga diputuskan bahwa penelitian ini menolak Ho dan menerima Ha (p-value $<0.05$ ). Hal ini berarti bahwa leverage berpengaruh signifikan negatif terhadap earnings response coefficient.

2. Pengaruh profitabilitas terhadap earnings response coefficient dapat dilihat nilai p-value yang dihasilkan 0.17 dengan koefisien jalur sebesar -0.15 , sehingga diputuskan bahwa penelitian ini menerima Ho dan menolak Ha (p-value $<0.05$ ).

3. Pengaruh investment opportunity set terhadap earnings response coefficient dapat dilihat nilai p-value yang dihasilkan 0.38 dengan koefisien jalur sebesar -0.05 , sehingga diputuskan bahwa penelitian ini 
menerima Ho dan menolak Ha (p-value < $0.05)$.

4. Pengaruh konservatisme akuntansi terhadap earnings response coefficient dapat dilihat nilai p-value yang dihasilkan 0.37 dengan koefisien jalur sebesar -0.05 , sehingga diputuskan bahwa penelitian ini menerima Ho dan menolak Ha (p-value $<0.05$ ).

5. Pengaruh konservatisme akuntansi terhadap hubungan antara leverage dengan earnings response coefficient dapat dilihat nilai p-value yang dihasilkan 0.42 dengan koefisien jalur sebesar 0.03, sehingga diputuskan bahwa penelitian ini menerima Ho dan menolak Ha (p-value $<0.05$ ).

6. Pengaruh konservatisme akuntansi terhadap hubungan antara profitabilitas dengan earnings response coefficient dapat dilihat nilai p-value yang dihasilkan 0.47 dengan koefisien jalur sebesar 0.01, sehingga diputuskan bahwa penelitian ini menerima Ho dan menolak Ha (p-value $<0.05$ ).

7. Pengaruh konservatisme akuntansi terhadap hubungan antara investment opportunity set dengan earnings response coefficient dapat dilihat nilai p-value yang dihasilkan 0.00 dengan koefisien jalur sebesar 0.43 , sehingga diputuskan bahwa penelitian ini menolak Ho dan menerima Ha (p-value < 0.05).

8. Pengujian variabel control yaitu persistensi laba terhadap earnings response coefficient dapat dilihat nilai p-value yang dihasilkan $<0.00$ dengan koefisien jalur sebesar 0.47, sehingga diputuskan bahwa penelitian ini menolak Ho dan menerima Ha (p-value < $0.05)$. Artinya persistensi laba berpengaruh signifikan positif terhadap earnings response coefficient.
Tabel 4. Path Cofficient dan P-Value

\begin{tabular}{lcc}
\hline \multicolumn{1}{c}{ Jalur } & $\begin{array}{c}\text { Path } \\
\text { Coeficient }(\boldsymbol{\beta})\end{array}$ & P-Value \\
\hline $\mathrm{DER} \rightarrow$ ERC & -0.29 & 0.02 \\
$\mathrm{ROE} \rightarrow$ ERC & -0.15 & 0.17 \\
$\mathrm{IOS} \rightarrow$ ERC & -0.05 & 0.38 \\
$\mathrm{CA} \rightarrow$ ERC & -0.05 & 0.37 \\
$\mathrm{DER} * \mathrm{CA} \rightarrow$ ERC & 0.03 & 0.42 \\
$\mathrm{ROE} * \mathrm{CA} \rightarrow$ ERC & 0.01 & 0.47 \\
$\mathrm{IOS} * \mathrm{CA} \rightarrow$ ERC & 0.43 & 0.00 \\
EP $\rightarrow$ ERC & 0.47 & $<0.00$ \\
\hline
\end{tabular}

Sumber : Hasil WarpPLS (data diolah)

\section{Pengaruh Leverage Terhadap Earnings Response Coefficient}

Hasil penelitian menunjukkan bahwa leverage berpengaruh negatif terhadap earnings response coefficient. Leverage menunjukkan perbandingan antara hutang dengan modal, dengan kata lain bahwa leverage menunjukkan perbandingan antara jumlah dana yang disediakan oleh kreditor dan pemilik perusahaan. Leverage yang diukur oleh Debt to Equity Ratio (DER) menunjukkan bahwa semakin tinggi nilai rasio maka semakin tinggi jumlah hutang perusahaan sehingga semakin rendah rasio ini maka semakin baik kemampuan perusahaan dalam membayar kewajiban jangka panjangnya. Ketika leverage menunjukkan komposisi total hutang yang semakin besar dibandingkan dengan modal yang dimiliki maka berdampak pada semakin besar beban perusahaan terhadap kreditor. Meningkatnya beban terhadap kreditur menunjukkan sumber modal perusahaan bergantung pada pihak luar. Sehingga beban hutang yang ditanggung perusahaan dapat mengurangi laba yang diterima perusahaan. Maka dari itu, semakin tinggi rasio leverage perusahaan akan dipandang negatif oleh investor. Hasil penelitian ini sejalan dengan penelitian Yohan (2015), Suhartono (2015), dan Malahayati (2015) bahwa leverage berpengaruh 
signifikan negatif terhadap ERC. Namun tidak sejalan dengan penelitian Hasanzade, et al (2013) dan Sondang (2017).

\section{Pengaruh Profitabilitas Terhadap Earnings Response Coefficient}

Hasil uji statistik menunjukkan bahwa profitabilitas yang diukur dengan Return of Equity (ROE) tidak memiliki pengaruh signifikan terhadap ERC. Hal ini menunjukkan bahwa perusahaan yang memiliki profitabilitas tinggi yang diukur berdasarkan ekuitas belum tentu memiliki ERC yang tinggi karena investor tidak terpaku untuk mengambil keputusan ekonomi hanya kepada faktor profitabilitas. Profitabilitas perusahaan yang diharapkan menjadi sebuah sinyal atau penanda bahwa perusahaan dalam keadaan baik telah gagal untuk menarik respon para investor karena terdapat informasi dari faktor-faktor lain yang terkandung di dalam pengumuman laba yang lebih menarik dan lebih memiliki informativeness bagi mereka untuk mengambil keputusan sehingga teori signaling tidak berlaku dalam penelitian ini. Hasil dari penelitian ini sesuai dengan hasil penelitian yang dilakukan oleh Santoso (2015) yang menunjukkan bahwa profitabilitas tidak mempengaruhi secara signifikan terhadap ERC.

\section{Pengaruh Investment Opportunity Set Terhadap Earnings Response Coefficient}

Hasil uji statistik menunjukkan bahwa investment opportunity set yang diukur dengan market to book ratio tidak memiliki pengaruh signifikan terhadap ERC. Hal ini mengindikasikan bahwa pasar tidak mereaksi koefisien respon melalui variabel investment opportunity set yang diproksikan dengan market to book ratio. Investment opportunity set merupakan kesempatan yang dimiliki oleh suatu perusahaan untuk bertumbuh. Investment opportunity set digunakan sebagai dasar untuk menentukan klasifikasi pertumbuhan perusahaan di masa mendatang. Sehingga nilai investment opportunity set yang menunjukkan tidak memiliki pengaruh signifikan mengindikasikan bahwa investor kurang memperhatikan nilai investment opportunity set dan investor hanya memiliki motif jangka pendek untuk mendapatkan keuntungan. Penelitian ini sesuai dengan peneilitian Santoso (2015) namun tidak sejalan dengan penelitian Mashayekhi, et al (2016) yang menyatakan bahwa investment opportunity set berpengaruh terhadap ERC.

\section{Pengaruh Konservatisme Akuntansi Terhadap Earnings Response Coefficient}

Hasil uji statistik menunjukkan konservatisme akuntansi tidak memiliki pengaruh signifikan terhadap ERC. Hal ini menunjukkan bahwa prinsip konservatisme akuntansi yang digunakan perusahaan dalam pelaporan keuangan tidak mampu meningkatkan reaksi investor. Penerapan standar IFRS yang diberlakukan pada tahun 2012, prinsip konservatisme akuntansi diganti dengan prinsip prudence walaupun pada dasarnya prinsip konservatisme akuntansi tidak sepenuhnya hilang. Prinsip prudence dalam IFRS terutama yang berhubungan dengan pendapatan adalah pendapatan boleh diakui meskipun masih berupa potensi, sepanjang memenuhi ketentuan pengakuan pendapatan (revenue recognition) dalam IFRS. Sedangkan pada prinsip konservatisme lebih cepat mengakui beban dan menunda pengakuan pendapatan. Sehingga mengakibatkan pilihan metode akuntansi ditujukan pada metode yang melaporkan laba dan asset yang lebih rendah serta melaporkan hutang yang lebih tinggi. Hasil penelitian ini tidak sejalan dengan penelitian (Suhartono, 2015; Basuki, 2017) yang menyimpulkan bahwa konservatisme akuntansi berpengaruh positif terhadap ERC.

\section{Konservatisme Akuntansi Memoderasi Pengaruh Leverage Terhadap Earnings Response Coefficient}

Prinsip konservatisme akuntansi sebagai prinsip kehati-hatian dalam merespon 
ketidakpastian tidak mampu memoderasi pengaruh leverage terhadap ERC. Kenaikan atau penurunan tingkat hutang perusahaan tidak dipengaruhi oleh penerapan prinsip konservatisme akuntansi yang diterapkan perusahaan. Penelitian ini tidak sejalan dengan penelitian yang dilakukan oleh Suhartono (2015) yang menyatakan bahwa konservatisme akuntansi berpengaruh signifikan negatif terhadap hubungan leverage dengan ERC.

\section{Konservatisme Akuntansi Memoderasi Pengaruh Profitabilitas Terhadap Earnings Response Coefficient}

Prinsip konservatisme akuntansi sebagai prinsip kehati-hatian dalam merespon ketidakpastian tidak mampu memoderasi pengaruh profitabilitas terhadap ERC. Penerapan prinsip ini mengakibatkan pilihan metode akuntansi ditujukan pada metode yang melaporkan laba atau aktiva yang lebih rendah serta melaporkan hutang lebih tinggi. Investor tidak merespon penerapan konservatisme akuntansi yang diterapkan perusahaan sehingga kenaikan ataupun penurunan profitabilitas perusahaan tidak dipengaruhi oleh penerapan prinsip konservatisme akuntansi. Hal ini tidak sejalan dengan penelitian Wardhani (2008) bahwa perusahaan yang memperoleh keuntungan lebih cenderung untuk menggunakan prinsip akuntansi konservatif. Hasil penelitian ini juga tidak konsisten dengan Saputri (2013) yang menyatakan bahwa terdapat pengaruh positif antara profitabilitas dengan konservatisme akuntansi.

\section{Konservatisme Akuntansi Memoderasi Pengaruh Investment Opportunity Set Terhadap Earnings Response Coefficient}

Prinsip konservatisme akuntansi sebagai prinsip kehati-hatian dalam merespon ketidakpastian mampu memoderasi pengaruh investment opportunity set terhadap ERC. Investment opportunity set merupakan angka yang menunjukkan tingkat pertumbuhan yang dimiliki perusahaan. Tingkat pertumbuhan penjualan yang tinggi seringkali meningkatkan ekspektasi pasar terhadap arus kas di masa depan sehingga akan mempengaruhi penerapan konservatisme akuntansi perusahaan sebagai suatu prinsip kehati-hatian dalam menghadapi ketidakpastian yang melekat pada perusahaan untuk mencoba mengantisipasi kemungkinan apabila ternyata terjadi kerugian. Hal ini mengindikasikan adanya hubungan positif antara IOS dengan konservatisme akuntansi menggunakan pengukuran akrual. Semakin tinggi nilai IOS yang menunjukkan tingkat pertumbuhan perusahaan maka semakin tinggi konservatisme akuntansi yang diterapkan perusahaan dan memberikan pengaruh positif terhadap ERC.

\section{Pengaruh Persistensi Laba Terhadap Earnings Response Coefficient}

Hasil penelitian menunjukkan bahwa persistensi laba berpengaruh signifikan positif terhadap earnings response coefficient. Dengan kata lain bahwa semakin persisten suatu laba maka semakin tinggi reaksi investor. Hal ini sesuai dengan Tuwentina dan Wirama (2014) menyatakan bahwa laba yang lebih persisten akan memiliki kualitas laba yang lebih tinggi dibandingkan dengan laba yang kurang persisten. Teori signaling menyatakan bahwa pengumuman laba sebagai sinyal baik (good news) bagi investor yaitu berupa kenaikan laba perusahaan yang memberikan pengaruh terhadap reaksi investor yang dicerminkan pada kenaikan harga saham. Teori hipotesis pasar setengah kuat melandasi tentang value relevance informasi laba (pengaruh pengumuman laba terhadap reaksi investor) bahwa laba memiliki nilai relevansi yang diketahui dari pengaruhnya terhadap reaksi investor yang digambarkan dalam harga saham. Semakin besar laba maka reaksi invetor akan semakin tinggi. Hal ini sejalan dengan penelitian Jaya (2015) dan Malahayati (2015) menyatakan bahwa persistensi laba berpengaruh positif terhadap earnings response coefficient. 


\section{Kesimpulan, Keterbatasan dan Saran}

Hasil pengujian membuktikan bahwa Leverage berpengaruh signifikan negatifterhadap earnings response coefficient. Profitabilitas yang diukur dengan Return of Equity (ROE) tidak memiliki pengaruh signifikan terhadap ERC. Investment opportunity set yang diukur dengan market to book ratio tidak memiliki pengaruh signifikan terhadap ERC. Konservatisme akuntansi tidak memiliki pengaruh signifikan terhadap ERC. Prinsip konservatisme akuntansi sebagai prinsip kehati-hatian dalam merespon ketidakpastian tidak mampu memoderasi pengaruh leverage dan profitabilitas terhadap ERC. Prinsip konservatisme akuntansi sebagai prinsip kehati-hatian dalam merespon ketidakpastian sebagai pure moderasi pengaruh investment opportunity set terhadap ERC.

Penelitian yang dilakukan oleh peneliti memiliki beberapa keterbatasan sebagai berikut:

1. Jendela pengamatan mengenai harga saham dan indeks harga saham ketika publikasi laporan keuangan hanya menggunakan waktu pengamatan 3 hari sebelum dan 3 hari sesudah publikasi laporan keuangan.

2. Sampel penelitian hanya terbatas pada perusahaan Property dan Real Estate yang terdaftar di BEI dengan 7 tahun periode penelitian.

3. Variabel penelitian yang digunakan untuk memprediksi ERC hanya terbatas pada leverage, profitabilitas, investment opportunity set, dan konservatisme akuntansi.

Berdasarkan kesimpulan dan hasil penelitian, maka diajukan saran sebagai berikut:

1. Disarankan untuk memperluas objek penelitian.

2. Disarankan untuk menggunakan variabel selain konservatisme akuntansi sebagai variabel moderasi yang memiliki perspektif sama sesuai objek penelitian.

3. Disarankan untuk menambahkan variabel independen selain variabel yang telah digunakan dalam penelitian ini, untuk memperoleh hasil yang lebih akurat.

4. Diharapkan untuk penelitian berikutnya, jendela pengamatan earnings response coefficient 3 hari sebelum dan 3 hari sesudah publikasi laporan keuangan dilakukan uji beda penelitian.

\section{Daftar Referensi}

An, Y. (2015). Earnings response coefficients and default risk: case of korean firms. International Journal of Financial Research, 6(2), 67-71.

Apriwenni, P. (2015). Dampak Pertumbuhan Laba, Persistensi Laba, Leverage, Ukuran Perusahaan, dan Kualitas Audit Terhadap Earnings Response Coefficient Pada Perusahaan Manufaktur. Jurnal Ekonomi Perusahaan, 22(2).

Arista, D., \& Astohar, A. (2012). Analisis Faktor-Faktor Yang Mempengaruhi Return Saham. Jurnal Ilmu Manajemen dan Akuntansi Terapan, 3(1).

Aryanti, G. A. P. S., \& Sisdyani, E. A. (2016). Profitabilitas Pada Earnings Response Coefficient Dengan Pengungkapan Corporate Social Responsibility Sebagai Variabel Pemoderasi. E-Jurnal Akuntansi, 171-199.

Basuki, S. A., Nahar, A., \& Ridho, M. (2017). Conservatism Accountancy, Profit Persistence and Systematic Risk Towards The Earnings Responses Coefficient. Sriwijaya International Journal of Dynamic Economics and Business, 1(1), 77-102.

Delvira, M., \&Nelvirita, N. (2013). Pengaruh Risiko Sistematik, Leverage Dan Persistensi Laba Terhadap Earnings Response Coefficient (ERC). Wahana Riset Akuntansi, 1(1).

Eduardus, T. (2001). Analisis Investasi dan Manajemen Portofolio. BPFE UGM, Yogyakarta.

Fauzan, M., \&Purwanto, A. (2017). Pengaruh Pengungkapan Csr, Timeliness, 
Profitabilitas, Pertumbuhan Perusahaan Dan Resiko Sistematik Terhadap Earning Response Coefficient (ERC)(Studi Empiris Pada Perusahaan Manufaktur, Properti dan Pertambangan yang Terlisting di Bursa Efek Indonesia (BEI) pada periode 2013-2014). Diponegoro Journal of Accounting, 6(1), 256-270.

Givoly, D., \&Hayn, C. (2002). Rising conservatism: Implications for financial analysis. Financial Analysts Journal, 58(1), 56-74.

Gumanti, T. A. (2002). Underpricing dan Biaya-Biaya di Sekitar Initial Public Offering. Jurnal Akuntansi dan Keuangan Wahana, 5(2).

Haniati, S. Fitriany, 2010, Pengaruh Konservatisme Terhadap Asimetri Informasi dengan Menggunakan Beberapa Model Pengukuran Konservatisme. Simposium Nasional Akuntansi XIII, 1-28.

Hasanzade, M., Darabi, R., \& Mahfoozi, G. (2014). Factors affecting the earnings response coefficient: An empirical study for Iran. European Online Journal of Natural and Social Sciences: Proceedings, 2(3 (s)), pp-2551.

Husiano, D., \&Suratno, S. (2014). Analisis Pengaruh Beta, Leverage, Dividend Payout Ratio, dan Earnings Persistence terhadap Earnings Response Coefficient pada Indeks Kompas 100. JRAP (Jurnal Riset Akuntansi dan Perpajakan), 1(2).

Imam, G. (2013). Aplikasi Analisis Multivariate dengan Program IBM SPSS 21 Update PLS Regresi. Semarang. Badan Penerbit Universitas Diponegoro. ISBN, 979(015.1). Jogiyanto,H.(2010). Teori PortofoliodanAnalisis Investasi (Edisi Ketujuh). Yogyakarta: $B P F E$.

Juanda, A. (2014). Kandungan Prinsip Konservatisme Dalam Standar Akuntansi Keuangan Berbasis IFRS (International Financial Reporting Standard). Jurnal Humanity, 7(2).
Malahayati, R., Arfan, M., \&Basri, H. (2015). Pengaruh Ukuran Perusahaan Dan Financial LeverageterhadapPersistensi Laba, Dan Dampaknya Terhadap Kualitas Laba (Studi pada Perusahaan yang Terdaftar di Jakarta Islamic Index). Jurnal Administrasi Akuntansi: Program Pascasarjana Unsyiah, 4(4).

Marselina, L., \& Sebrina, N. (2014). Analisis Perbedaan Tingkat Konservatisme Akuntansi Sebelum dan Sesudah Konvergensi IFRS (Studi Empiris pada Perusahaan Manufaktur yang terdaftar di BEI Tahun 2008-2009 dan 20122013). Wahana Riset Akuntansi, 4(1).

Mashayekhi, B., \&Aghel, Z. L. (2016). A Study on the Determinants of Earnings Response Coefficient in an Emerging Market. International Journal of Social, Behavioral, Educational, Economic, Business and Insustrial Engineering, 10(7), 2454-2457.

Mulyani, S., Asyik, N. F., \&Andayani, A. (2007). Faktor-Faktor yang Mempengaruhi Earnings Response Coeficient pada Perusahaan yang Terdaftar di Bursa Efek Jakarta. Indonesian Journal of Accounting and Auditing, 11(1).

Purnamasari, K., Herdjiono, I., \& Setiawan, E. (2012). Financial risks, growth, earnings and stock returns relationship: The case of Indonesia. International Review of Business Research Papers, 8(7), 79-93.

Rajagukguk, S. M. (2018). Hubungan Antara Earning Response Coefficient dengan Karakteristik Perusahaan. Jurnal Akuntansi Maranatha, 9(2).

Santoso, G. (2015). Determinan Koefisien Respon Laba. Parsimonia-Jurnal Ekonomi dan Bisnis, 2(2), 69-85.

Saputri, Y. D. (2013). Faktor-faktor yang mempengaruhi pilihan perusahaan terhadap konservatisme akuntansi. Accounting Analysis Journal, 2(2).

Septiana, I. P., \&Tarmizi, M. I. (2015). 
Konservatisme Akuntansi, Efektivitas Komite Audit, Konsep Amanah Dan Manajemen Laba. Simposium Nasional Akuntansi, 18, 1-21.

Setyaningtyas, T. (2009). Pengaruh Konservatisme Laporan Keuangan Dan Siklus Hidup Perusahaan Terhadap Koefisien Respon Laba (Studi Pada Perusahaan Manufaktur Di Bursa Efek Jakarta Periode 2002-2006). Skripsi). Universitas Sebelas Maret Surakarta.

Subekti, I. (2005, September). Asosiasi Antara Praktik Perataan Laba dan Reaksi Pasar Modal di Indonesia. In Symposium Nasional Akuntansi VIII, Solo.

Subramanyam, K. R., \& Wild, J. J. (2010). Analisis Laporan Keuangan, edisi kesepuluh buku2. Terjemahan oleh Dewi Yanti.

Suhartono, S. (2015). Pengaruh Ukuran Perusahaan, Struktur Modal, Dan
Ketepatan Waktu Penyampaian Laporan Keuangan Terhadap Koefisien Respon Laba Yang Dimoderasi Konservatisme Akuntansi. Jurnal Ekonomi Perusahaan, 22(2).

Tuwentina, P., \&Wirama, D. G. (2014). Pengaruh Konservatisme Akuntansi dan Good Corporate Governance pada Kualitas Laba. E-Jurnal Akuntansi, 185-201.

Wardhani, R. (2008). Tingkat konservatisme akuntansi di Indonesia dan hubungannya dengan karakteristik dewan sebagai salah satu mekanisme corporate governance. Simposium Nasional Akuntansi XI, 1-26.

Watts, R. L. (2003). Conservatism in accounting part I: Explanations and implications. Accounting horizons, 17(3), 207-221. 